\title{
Remediation of Oil-Contaminated Soil in Greenland
}

\author{
Fritt-Rasmussen, Janne; Jensen, Pernille Erland
}

Published in:

ISCORD 2013. Planning for sustainable cold regions

Publication date:

2013

Document Version

Publisher's PDF, also known as Version of record

Link back to DTU Orbit

Citation (APA):

Fritt-Rasmussen, J., \& Jensen, P. E. (2013). Remediation of Oil-Contaminated Soil in Greenland. In ISCORD 2013. Planning for sustainable cold regions (pp. 105-115). American Society of Civil Engineers.

\section{General rights}

Copyright and moral rights for the publications made accessible in the public portal are retained by the authors and/or other copyright owners and it is a condition of accessing publications that users recognise and abide by the legal requirements associated with these rights.

- Users may download and print one copy of any publication from the public portal for the purpose of private study or research.

- You may not further distribute the material or use it for any profit-making activity or commercial gain

- You may freely distribute the URL identifying the publication in the public portal

If you believe that this document breaches copyright please contact us providing details, and we will remove access to the work immediately and investigate your claim 


\title{
Remediation of Oil-Contaminated Soil in Greenland
}

\author{
Janne Fritt-Rasmussen, $\mathrm{PhD}$ \\ Arctic Technology Centre, Technical University of Denmark, Kgs. Lyngby, Denmark \\ (Present affiliation: Danish Centre for Environment and Energy, Aarhus University, Roskilde, \\ Denmark) \\ Pernille Erland Jensen, PhD \\ Arctic Technology Centre, Technical University of Denmark, Kgs. Lyngby, Denmark
}

\begin{abstract}
This paper present the recent research conducted at the Arctic Technology Centre, where different solutions for remediation of excavated oil contaminated soil in Greenlandic towns were tested.

In the first work, soil polluted by light oil was treated with two different nutrient sources (substrate and $\mathrm{N}: \mathrm{P}: \mathrm{K})$, stabilizer (crab shells) and heating $\left(20^{\circ} \mathrm{C}\right)$. In this work a clear reduction in hydrocarbon content was observed during the treatment period of 730 days. No significant difference in degradation was observed between the two different nutrient sources, and no effect of crab shells was observed. The degradation proceeded further at the elevated temperature and even more when heat and nutrients were combined.

In the second work, a nutrient rich soil highly polluted by weathered heavy oil was aerated by insertion of air-channels, and heated to $20^{\circ} \mathrm{C}$. Between $19 \%$ and $34 \%$ of the oil pollution was removed during the 81 days of the experiment. Analysis by Gas Chromatography-Flame Ionization Detector showed that the lighter fractions were removed, while the heavy oils remained. In the third experiment the oil contaminated soil is subjected to sequential treatment including adding of surplus heat from the local waste incineration plant. The results showed the highest reduction of the oil-contamination for the set-up with a combination of heat and sphagnum.
\end{abstract}

KEY WORDS: Greenland, oil-contamination, remediation, Arctic, soil

\section{INTRODUCTION}

Oil spills are often a problem in towns in Greenland, where oil is used for heating and transportation. The problem may increase in the future with expected oil exploitation in Greenlandic marine areas and related terrestrial activities. Oil undergoes natural microbial degradation, for which nutrients, temperature, water content, $\mathrm{pE}$ and $\mathrm{pH}$ are important factors for the degradation rate. In particular temperature and nutrient availability are challenges in the Arctic, and alternative solutions must be sought if bioremediation is to be implemented as a low-cost and low-tech solution in this region.

One of the major issues related to biodegradation in the Arctic is the low temperatures; however it has been shown that there is microbial activity at temperatures below $0^{\circ} \mathrm{C}$. 
Rike et al. (2003) found that a natural biodegradation of oil contamination occurred at temperatures below $0^{\circ} \mathrm{C}$ and also showed that the abundance of the number of microorganisms that are able to degrade oil increases with increasing pollution. Mohn and Stewart (2000), however showed that the degradation rate increased with a temperature increase from 7 to $15{ }^{\circ} \mathrm{C}$. Thus low temperature is not directly inhibiting the microbial activity, but more likely it inhibits the mass transfer and the physical conditions for the components in the soil (Eriksson et al., 2001), resulting in a slower degradation in the Arctic compared to regions with a warmer climate.

From experiments in the Arctic it was shown that during the summer months with increased temperatures, oxygen may be a limiting factor for the degradation (Rike et al. 2003; 2005). However, adding nutrients such as nitrogen and phosphorus has also shown a positive effect and stimulates the degradation (Mohn and Stewart 2000). An initiative that showed promising results was the application of land farming. This was tested in Alaska on a $3600 \mathrm{~m}^{3}$ contaminated site, where the clean-up was completed within 65 days (McCarthy et al. 2004). As part of the land farming nutrients were added and the soil was turned regularly, thereby supplying oxygen. However it is not completely clear whether or not it was the oxygen or the nutrients or the combination that was the primary reason for the fast removal.

Overall, the literature shows that it is possible to degrade oil under arctic conditions and also that it is possible to increase the degradation by applying different initiatives.

Since 2002 several experiments have been conducted at the Arctic Technology Centre in Sisimiut, Greenland to gain more knowledge about enhanced degradation of oil polluted soil in an Arctic climate. The purpose of our paper is to give an overview of the experiments, highlight the most important findings and thereby give recommendations for further works. For more details and additional analysis the following reports can be consulted: Andersen et al., 2002; Fritt-Rasmussen and Nielsen, 2005; Paamand and Pade, 2008 and Højrup, 2012.

\section{MATERIALS AND METHODS}

\subsection{The First Approach}

In 2002 a site investigation confirmed that the former Greenland Technical Organisation (GTO) site in Sisimiut, Greenland was polluted with light oil. Soil from the GTO-site was excavated and divided into 12 wooden boxes each containing approximately $90 \mathrm{~L}$ of soil. Nine of the boxes were covered with plastic and three of the boxes were covered with airand water-permeable felt. Different sources of nutrient (substrate and N:P:K) and stabilizer (crab shells - applied as they constitute a locally available waste product) were added to the boxes. Nine boxes were placed outside and the remaining three were placed at room temperature $\left(20^{\circ} \mathrm{C}\right)$. An overview of the content in each of the 12 boxes is given in Table 1 below. 
Table 1: Overview of the experimental set-up for the First Approach.

\begin{tabular}{ll}
\hline $\begin{array}{l}\text { Sample } \\
\text { ID }\end{array}$ & Experimental set-up \\
\hline I & Crab shells + N:P:K \\
II & Crab shells + Substrate \\
III & Crab shells \\
IV & Reference \\
V & Substrate \\
VI & N:P:K $(6: 1: 5)$ \\
VII & Drainage \\
VIII & Draining + Substrate \\
IX & Draining + N:P:K \\
X & Heating \\
XI & Heating + Substrate $\left(20^{\circ} \mathrm{C}\right)$ \\
XII & Heating + N:P:K $\left(20^{\circ} \mathrm{C}\right)$ \\
\hline
\end{tabular}

Based upon the findings from the first approach a new experiment was established in 2003 to further investigate the effect of heating in more detail. 6 boxes were placed in a "tent" made of blue PVC plastic and into each box was added a source of nutrient $(\mathrm{N}: \mathrm{P}: \mathrm{K})$. A solar air collector system was installed for heat supply to the boxes. An illustration of the set-up can be seen in the pictures below (Figure 1).

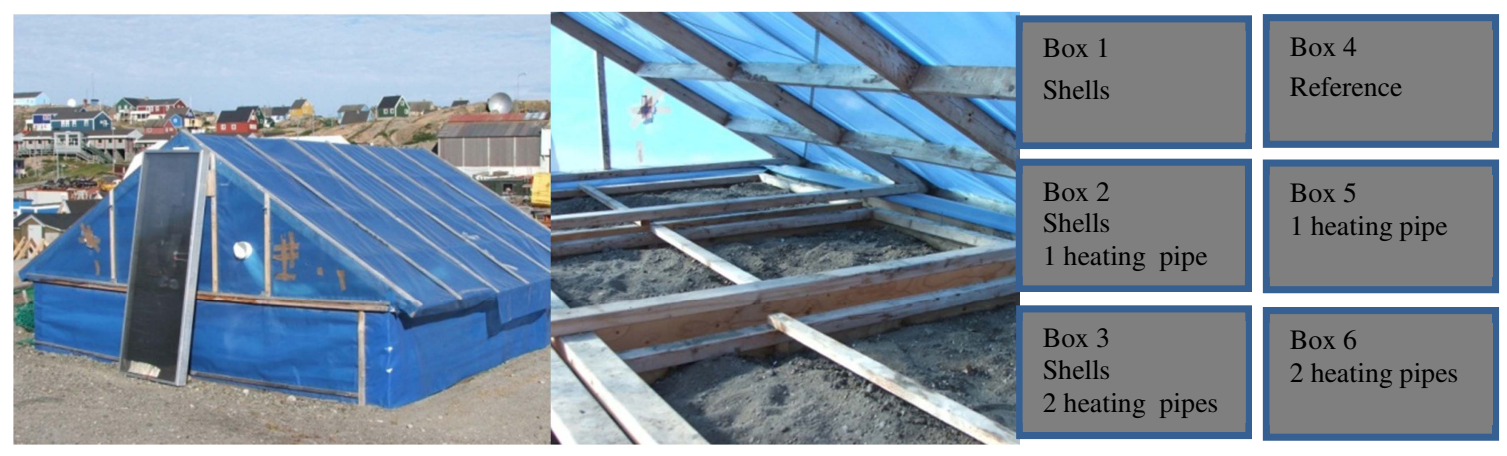

Figure 1: First approach set-up part two. The excavated soil was placed in the "tent" (left picture) in wooden boxes (middle picture). Heat was generated by solar power.

\subsection{The Second Approach}

In 2005 a new set-up was constructed. Soil which was highly polluted by weathered heavy oil but also highly nutrient-rich was excavated from the waste dump in Sisimiut. Before the start of the experiment the soil was homogenized by mixing and large stones were removed. The soil was placed in 12 boxes with four parallel experiments $(\mathrm{K} 1, \mathrm{~K} 2$, $\mathrm{K} 3$ and K4) each box containing about $56 \mathrm{~L}$ of soil. The boxes were aerated by insertion 
of air-channels and placed at room temperature $\left(20^{\circ} \mathrm{C}\right)$. An illustration of the set-up is shown in the Figure 2.

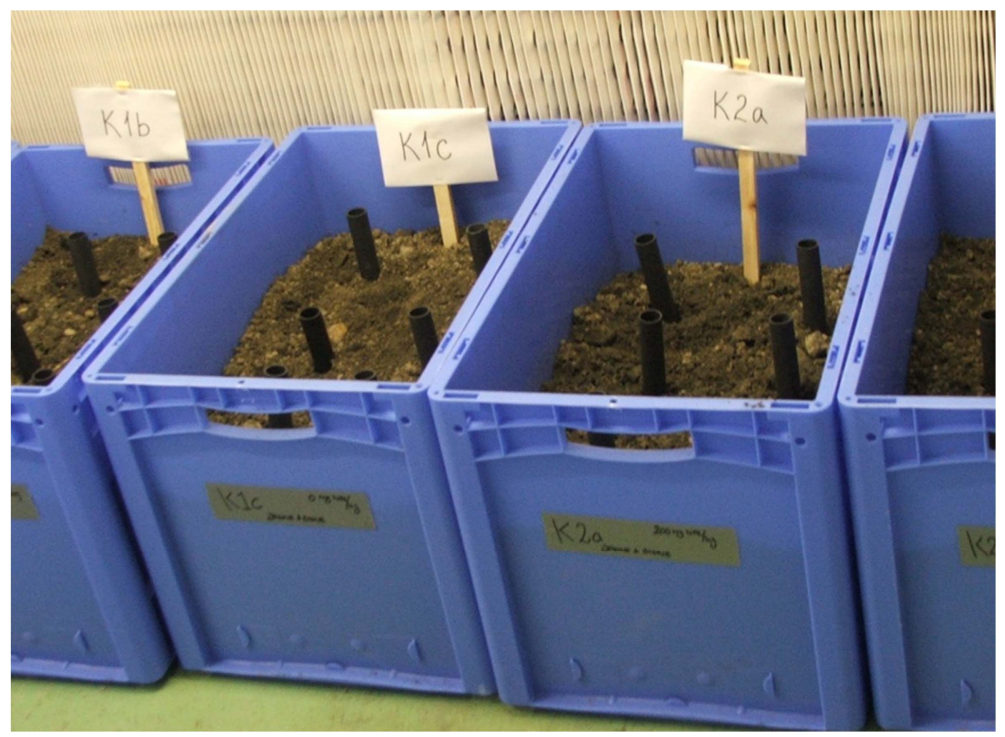

Figure 2: The second approach set-up. Perforated pipes constitute the aeration system due to convection.

\subsection{The Third Approach}

In the third approach, soil contaminated by light Arctic gas oil was screened and mixed with sphagnum moss and chalk prior to experiment. During the experiment it was heated by a supply of surplus heat from the local waste incineration plant. The set-up is shown in Figure 3.

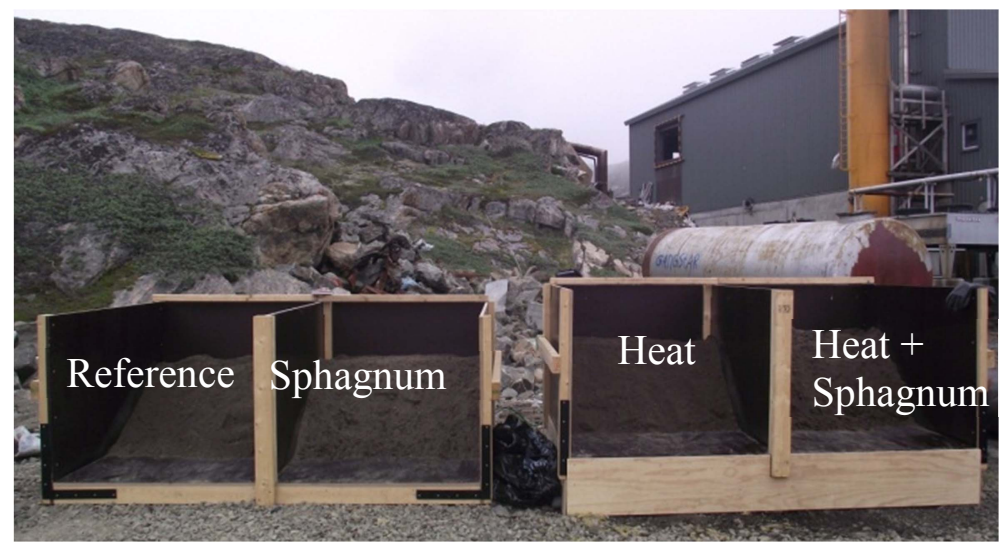

Figure 3: Boxes with oil-contaminated soil and different additions. The addition of sphagnum includes both sphagnum moss and chalk. 


\subsection{Hydrocarbon Analysis}

The total content of hydrocarbon (THC) was measured in the soil samples by gas chromatograph with a flame ionization detector (GC-FID). Two different methods were used. The oil samples from the first approach were analyzed by use of the method "Dansk Chemtex nr. 1". Prior to analysis, the samples were mixed with water and extracted with dichloromethane. The rest of the samples were prepared and analyzed by used of a modified method of REFLAB (1998). The samples were mixed with $20 \mathrm{ml} 0.05 \mathrm{M}$ Sodium pyrophosphate decahydrate prior to analysis and $20 \mathrm{ml}$ pentane with internal standard was added.

\section{RESULTS AND DISCUSSION}

\subsection{The First Approach}

Samples were taken after 0, 19 and 730 days and analyzed for the total content of hydrocarbons. The results can be found in Figure 4 .

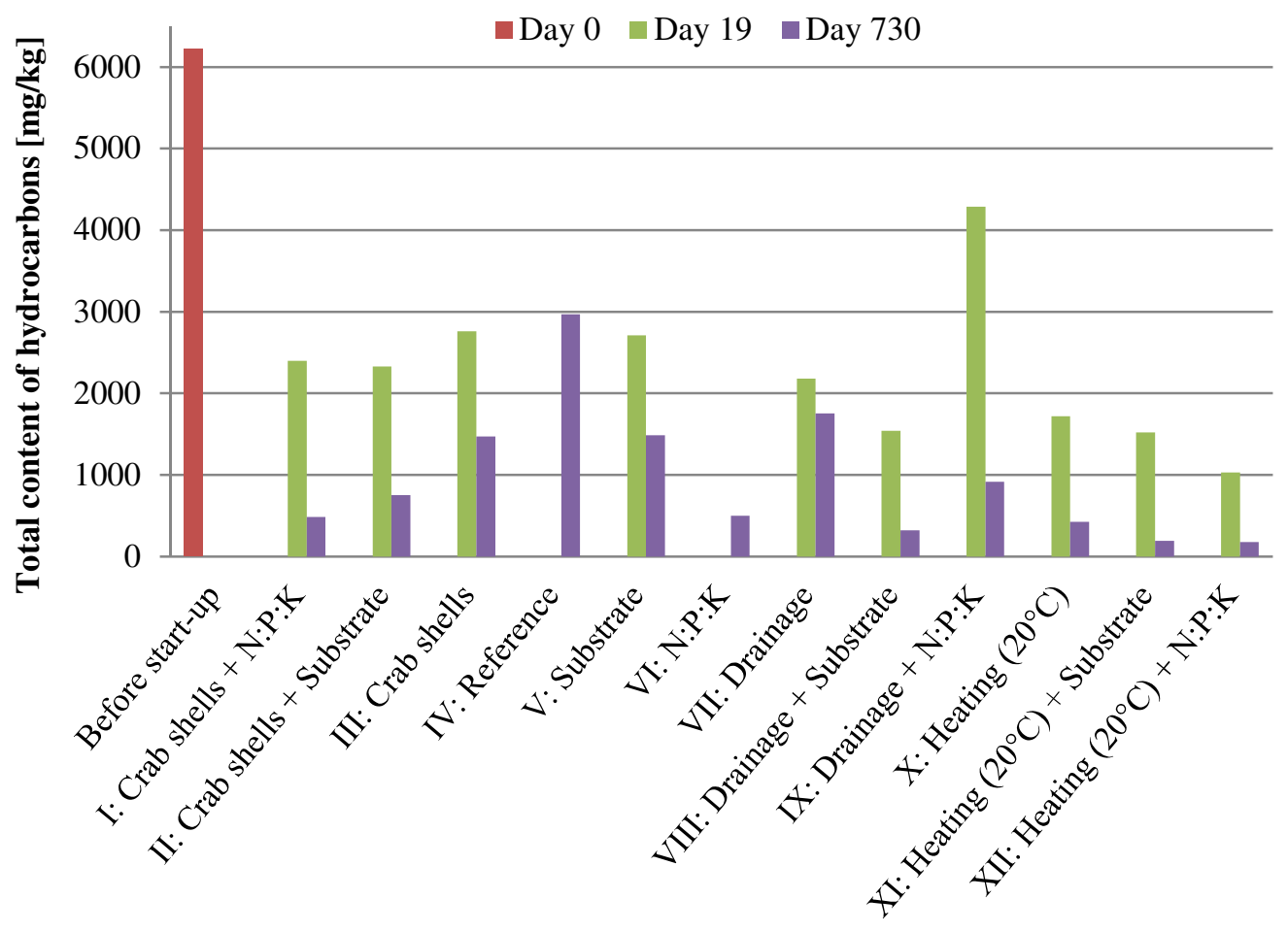


Figure 4: The content of hydrocarbons in the samples from the first approach. Data from Andersen et al. 2002 and Jensen and Fritt-Rasmussen and Nielsen 2005.

From the results from the First Approach (Figure 4) with oil-contaminated soil from the GTO site in Sisimiut, a reduction of the oil-contamination was seen during the first 19 days and after two years the contamination was even further reduced. The addition of a nutrient source seems to have a positive effect on the degradation of the oilcontamination regardless of the type of nutrient (substrate or $\mathrm{N}: \mathrm{P}: \mathrm{K}$ ). The reduction of the oil-contamination is higher at raised temperature $\left(20^{\circ} \mathrm{C}\right)$ compared to outdoor temperatures. The highest reduction in the contamination is seen for the experiments where a combination of heat and nutrients are applied to the soil. From Paamand and Pade, 2008 it was found that in-situ the pollution on the GTO site had decreased during a period of 13 years, however less than the soil which was treated. Thus, unenhanced natural degradation is taking place, however at a reduced pace.

The GC-FID results from samples taken in the "tent" are given in Figure 5. Based upon the findings from the first approach the "tent" experiments had the purpose to investigate the effect of heating in more detail. The results showed that the initial THC concentration of the oil-contaminated soil was very low and between 0 and $300 \mathrm{mg} / \mathrm{kg}$ total hydrocarbon. The majority of the oil was removed within the first days, and due to the infrequent sampling it is difficult to conclude anything about which parameter had the most effect on the degradation of the oil. 

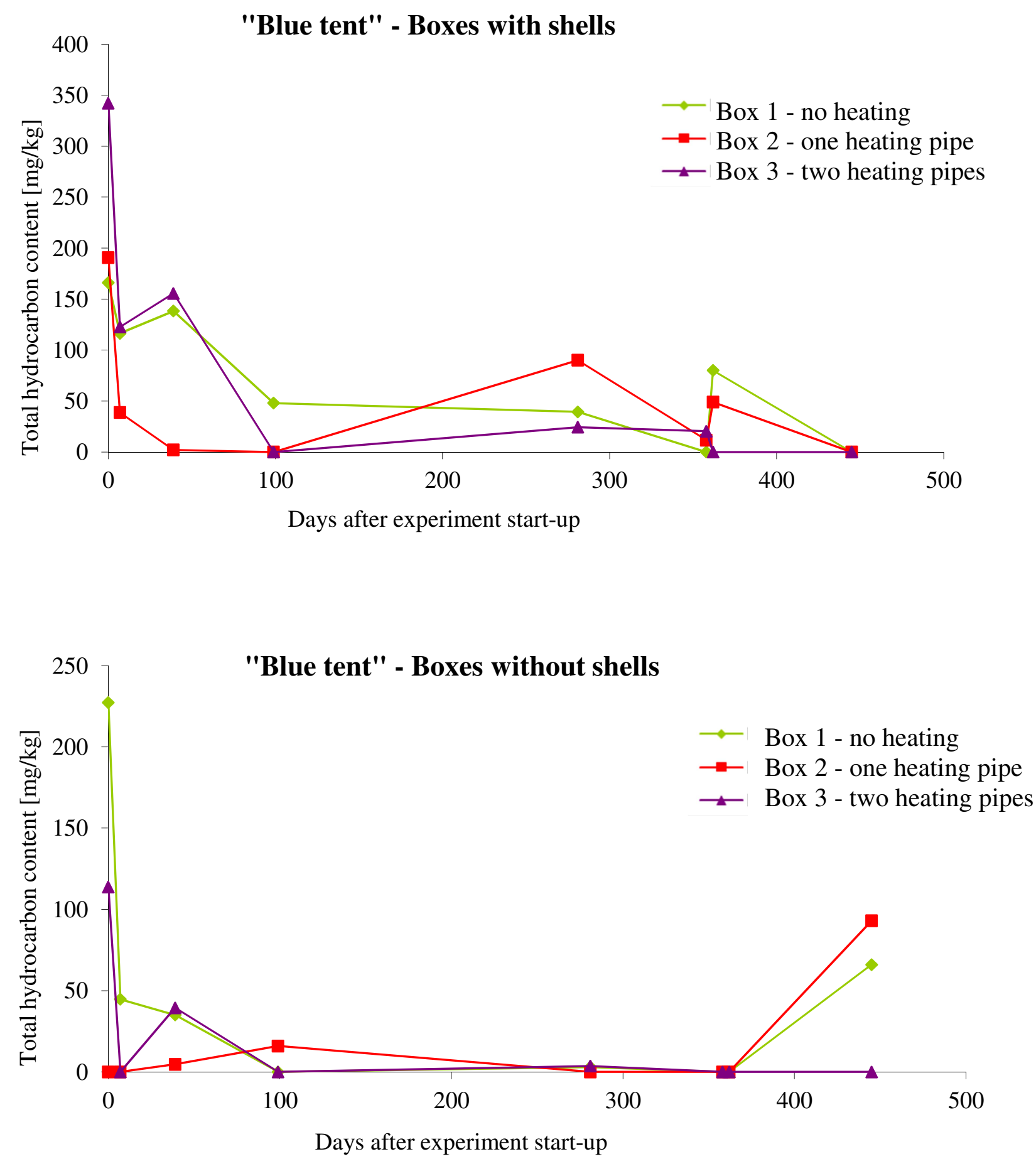

Figure 5: The content of hydrocarbons in the samples from the "blue tent" experiments as a function of time. Data from Fritt-Rasmussen and Nielsen 2005. 


\subsection{The Second Approach}

In the Second Approach (Figure 6) the initial concentration of total hydrocarbon in the soil was high with an average content of approximately $30900 \mathrm{mg} / \mathrm{kg}$. From the GC-FID chromatograms the oil was characterized as a highly weathered oil consisting of primarily aromatics and long chained n-alkanes. After 2.6 months a reduction between 19-34 \% of the total content of hydrocarbons was found as shown in Figure 6. The GCchromatograms also showed that it was primarily microbial degradation that took place during the experiments. This indicates that the heating and the initial homogenization of the oil-contaminated soil and oxidizing of the soil during the experiment improved the conditions for biodegradation. This can be seen from Figure 7 by comparison of the ratio of the n-alkane $\mathrm{nC}-17$ by the isoprenoid Pristine and the $\mathrm{n}$-alkane $\mathrm{nC}-18$ by the isoprenoid Phytane for the beginning and end of the experiments.

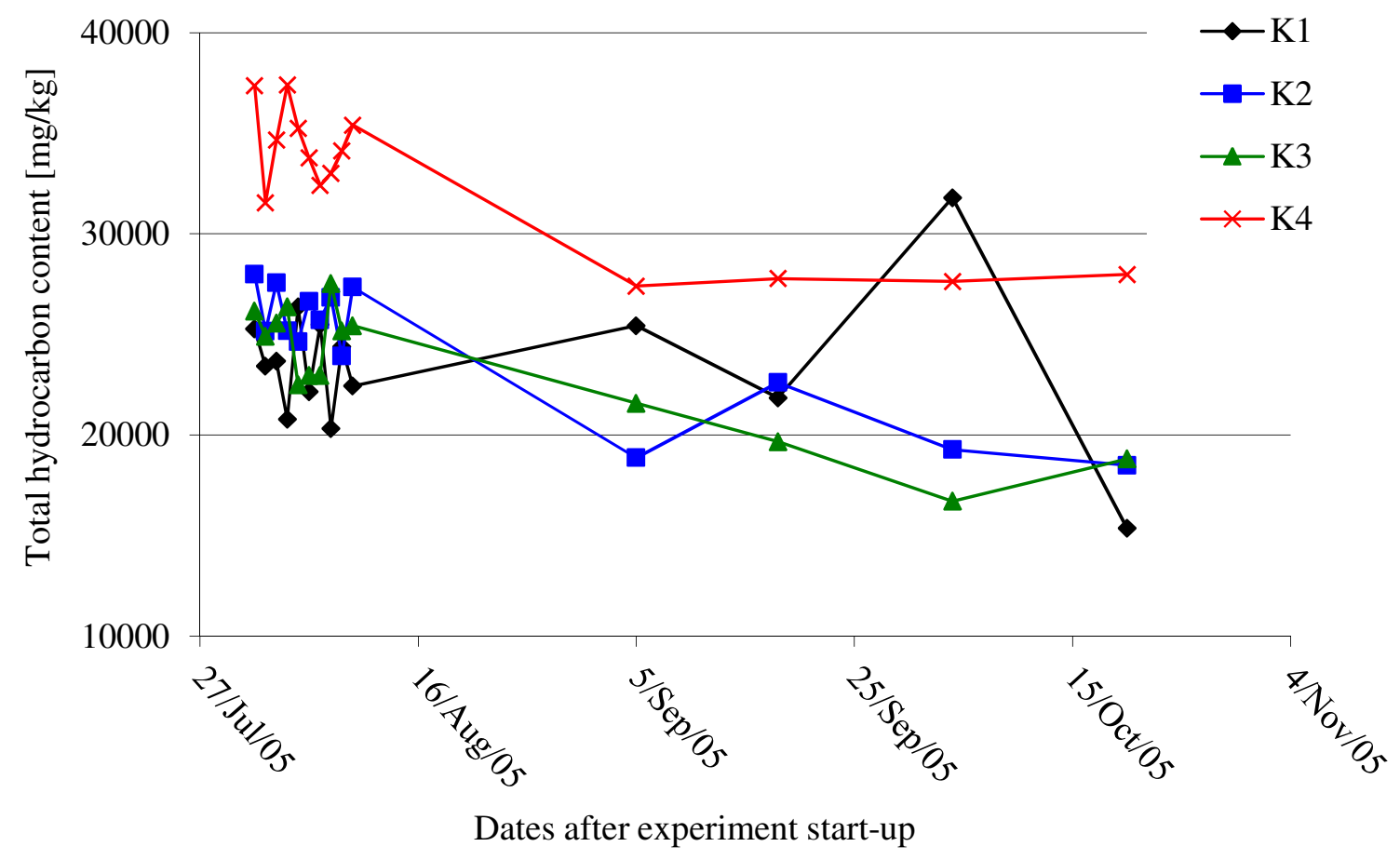

Figure 6: The average total content of hydrocarbons for the 4 parallel experiments, each with three replicates. K1-K4 indicates the four parallel experiments. 


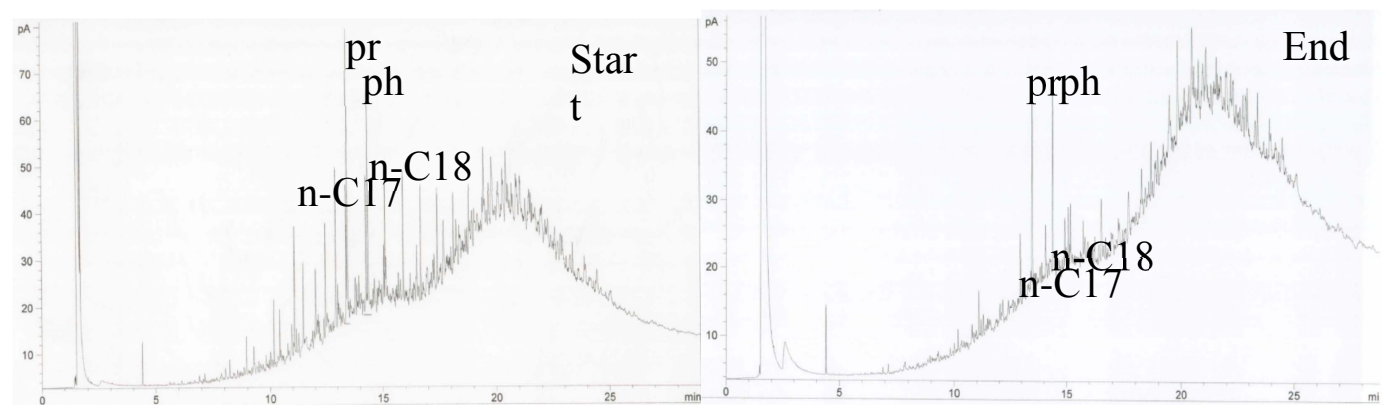

Figure 7: Examples of a GC-FID chromatogram from the start and end of the experiments.

\subsection{The Third Approach}

Samples from the third approach were taken after to screening and homogenization, at day 1, day 42 and day 168. The results can be seen in Figure 8.

The results from the third approach showed that the combination of heat and sphagnum resulted in the largest removal of the oil contamination. In general it should be noted that in spite of a large effort of homogenizing the soil initially, the oil was still somewhat heterogenic distributed in the soil.

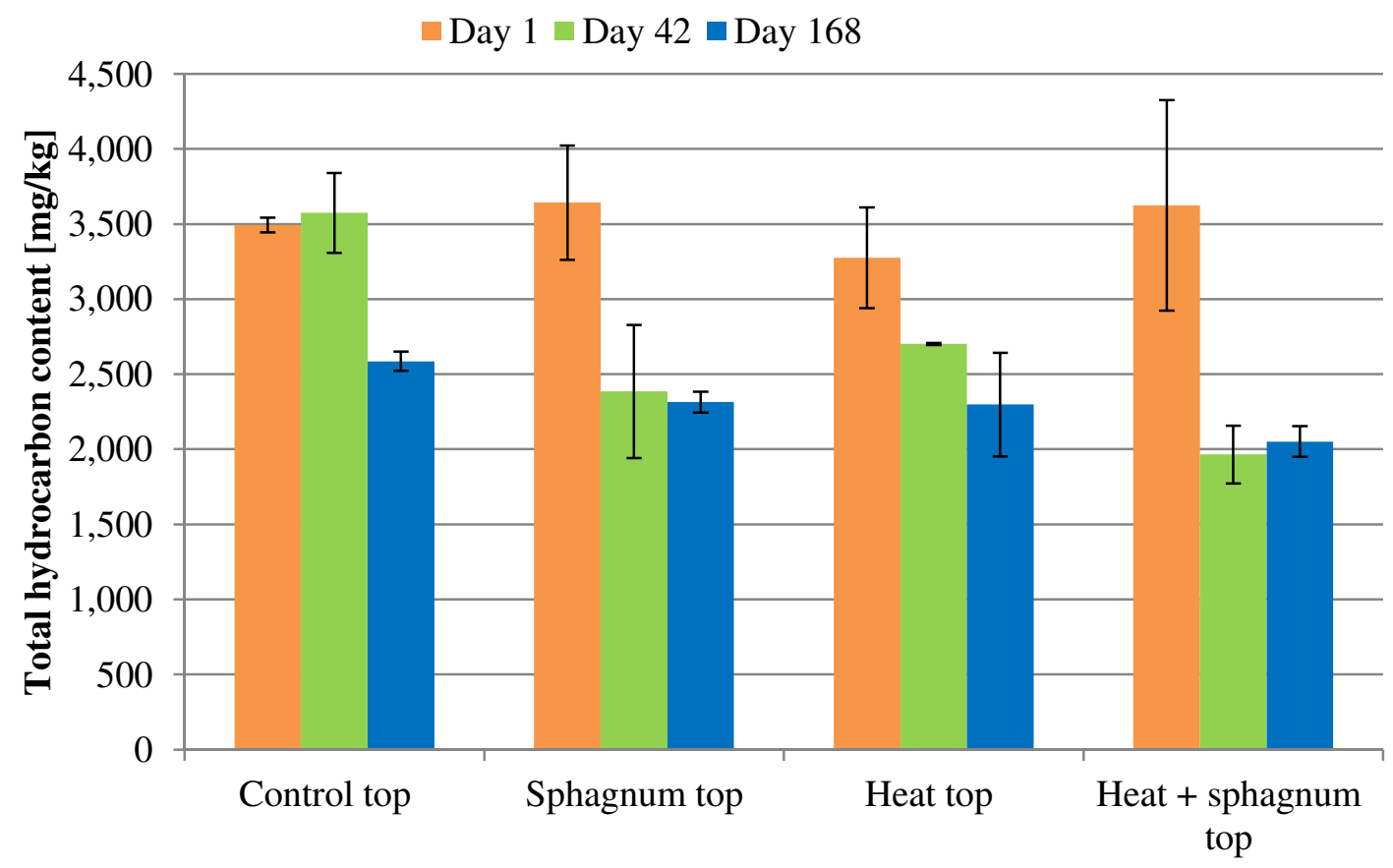


Figure 8: The development of total of hydrocarbons in the samples from the third approach.

The results show that the major reduction occurred between day 1 and 42 in the boxes with heat and/or sphagnum addition, while no reduction occurred in this period in the control box. The highest reduction was observed in the box with both sphagnum and heat, indicating a positive combined effect. This period was in late August to September with ambient temperatures above the freezing point. In this period the boxes with heating were heated to temperatures between approximately 20 and $50^{\circ} \mathrm{C}$ by surplus heat generated in the waste incineration plant. In the period between day 42 and 168, the temperature dropped to below $0^{\circ} \mathrm{C}$ and heating was switched off the system, as the incineration plant could sell all generated heat for the town's district heating system during this period. In this period a major reduction occurred in the control box while only limited reduction occurred in the boxes with heat and/or sphagnum addition. The results indicate that natural degradation has a longer lag-phase than the enhanced treatment, but that unenhanced treatment can reach same level as enhanced treatment with prolonged treatment time.

\section{CONCLUSION}

The results from the different experimental approaches of the treatment of oilcontaminated soil in Sisimiut show that there is a positive effect of turning the soil initially. Even though the soils and oil-contamination levels differed, an overall tendency is that application of a nutrient source in combination with heat is an effective solution. Depending on oil type, the weathering state of the oil and composition of the soil, different applications should be chosen to secure the best conditions for enhanced natural degradation of the oil-contamination.

All in all the results suggest that remediation of oil-contaminated soil is possible in the Arctic with low-tech and low-cost solutions.

\section{ACKNOWLEDGEMENT}

The authors would like to thank Mads Højrup, Signe Nielsen, Henrik Thalbitzer Andersen, Tobias-Henrik Andersen, Søren Feilberg Rasmussen and Malene Møller for their contributions to this paper.

\section{REFERENCES}

Andersen, H.T., Andersen, T-H., Rasmussen, S.F., 2002. Unders $\phi$ gelse af olieforurenet 
grund i Sisimiut, samt rensning af jorden ved kompostering. Student project, Arctic Technology Centre, Technical University of Denmark. (In Danish)

Eriksson, M., Ka, J-O., Mohn, W.W., 2001. Effects of Low Temperature and FreezeThaw Cycles on Hydrocarbon Biodegradation in Arctic Tundra Soil. Applied and Environmental Microbiology, 67, 11, 5107-5112.

Ferguson, S.H., Franzmann, P.D., Revill, A.T., Snape, I., Rayner, J.L., 2003. The Effects of Nitrogen and Water on Mineralisation of Hydrocarbons in Diesel-Contaminated Terrestrial Antarctic Soils. Cold Regions Science and Technology, 37, 2, 197-212.

Fritt-Rasmussen, J. and Nielsen, S., 2005. Oprensning af olieforurenet jord i Grønland. Student project, Arctic Technology Centre, Technical University of Denmark. (In Danish).

Højrup, M., 2012. Remediation of oil-contaminated soiul in Arctic climate. Student project, Arctic Technology Centre, Technical University of Denmark. (In Danish).

McCarthy, K., Walker, L., Vigoren, L., Bartel, J., 2004. Remediation of Spilled Petroleum Hydrocarbons by In Situ Landfarming at an Arctic Site. Cold Regions Science and Technology, 40, 1-2, 31-39.

Mohn, W.W., Stewart, G.R., 2000. Limiting Factors for Hydrocarbon Biodegradation at Low Temperature in Arctic Soils. Soil Biology \& Biochemistry, 32, 1161-1172.

Mohn, W.W., Radziminski, C.Z., Fortin, M.-C., Reimer, K.J., 2001. On Site Bioremediation of Hydrocarbon-contaminated Arctic Tundra Soils in Inoculated Biopiles. Applied Microbiology and Biotechnology, 57, 1-2, 242-247.

Paamand, E. T. and Pade, D., M., 2008. Forureningsunders $\phi g e l s e$ af GTO pladsen $i$ Sisimiut. Student project, Arctic Technology Centre, Technical University of Denmark. (In Danish).

REFLAB, 1998. Bestemmelse af olie i jord, Gaskromatografisk metode. Reflab metode 1:1998, 1.udgave (In Danish).

Rike, A.G., Haugen, K.B., Børresen, M., Engene, B., Kolstad, P., 2003. In Situ Biodegradation of Petroleum Hydrocarbons in Frozen Arctic Soils. Cold Regions Science and Technology, 37, 2, 97-120.

Rike, A.G., Haugen, K.B., Engene, B., 2005. In Situ Biodegradation of Hydrocarbons in Arctic Soils at Sub-zero Temperatures - Field Monitoring and Theoretical Simulation of the Microbial Activation Temperature at a Spitsbergen Contaminated Site. Cold Regions Science and Technology, 41, 3, 189-209. 